Syntax Literate: Jurnal Ilmiah Indonesia p-ISSN: 2541-0849

e-ISSN: 2548-1398

Vol. 6, No. 2, Februari 2021

\title{
ANALISIS STRATEGI PEMERINTAH DALAM UPAYA MENINGKATKAN KEPATUHAN WAJIB PAJAK YOUTUBER DI INDONESIA
}

\author{
Anita Carolina dan Inayati \\ Universitas Indonesia, Depok, Jawa Barat, Indonesia \\ Email: hutapeaanita@gmail.com dan inayati.hifni01@gmail.com
}

\section{Abstract}

Youtube, as one of the digitization products, has become a place that is sought after by various groups to get various sources of information and entertainment quickly and easily. From the results of uploading content, Youtuber will get income. When the income of some YouTubers far exceeds the income limit, it is not in accordance with the state tax revenue which almost never meets the target. As a country that adopts self-assessment, taxpayer compliance is the determinant of tax revenue. Therefore, a strategy is needed to increase the compliance of YouTubers in fulfilling their tax obligations. The purpose of this study is to analyze the factors that encourage and inhibit Youtuber compliance as taxpayers in Indonesia and explain the government's strategy in facing the digitalization era, especially in terms of implementing taxation policies on YouTubers' income. This research uses qualitative-descriptive research methods with in-depth interviews and documentation study data collection techniques. The results of this study are that there are several factors that hinder YouTubers in carrying out their tax obligations, such as the absence of cooperation between the DGT and Google and the absence of policies that regulate the income You get from uploading their content. In accordance with the background of the problem, it encourages the author to make a paper in the form of a thesis with the title, "Analysis of Government Strategies in Efforts to Improve Youtuber Taxpayer Compliance in Indonesia".

Keywords: tax administration; tax compliance; income tax; digital economy; youtuber

\section{Abstrak}

Youtube sebagai salah satu dari produk digitalisasi menjadi wadah yang dicari berbagai kalangan untuk mendapatkan berbagai sumber informasi dan hiburan dengan cepat dan mudah. Dari hasil mengunggah konten, Youtuber akan mendapatkan penghasilan. Disaat penghasilan beberapa Youtuber jauh melebihi batas penghasilan, tidak sesuai dengan penerimaan pajak negara yang hampir tidak pernah memenuhi target. Sebagai negara yang menganut self assessment, kepatuhan wajib pajak merupakan penentu penerimaaan pajak. Karena itu diperlukan strategi untuk meningkatkan kepatuhan youtuber dalam memenuhi kewajiban perpajakannya. Tujuan dari penelitian ini adalah menganalisis faktor yang mendorong serta menghambat kepatuhan Youtuber sebagai wajib pajak di Indonesia serta menjelaskan strategi pemerintah dalam menghadapi era digitalisasi khususnya dalam hal penerapan kebijakan perpajakan atas penghasilan YouTuber. Penelitian ini menggunakan metode penelitian kualitatif-deskriptif dengan teknik pengumpulan 
data wawancara mendalam dan studi dokumentasi. Hasil dari penelitian ini adalah terdapat beberapa faktor penghambat Youtuber dalam melakukan kewajiban perpajakannya seperti belum adanya kerjasama antara DJP dengan Google serta belum adanya kebijakan yang mengatur mengenai penghasilan yang didapat Youtuber dari pengunggahan kontennya. Sesuai dengan latar permasalahan tersebut mendorong penulis untuk membuat karya tulis dalam bentuk tesis dengan judul, "Analisis Strategi Pemerintah Dalam Upaya meningkatkan Kepatuhan Wajib Pajak Youtuber di Indonesia”.

Kata kunci: administrasi pajak; kepatuhan pajak; pajak penghasilan; ekonomi digital; youtuber

Coresponden Author

Email: hutapeaanita@gmail.com Artikel dengan akses terbuka dibawah lisensi

\section{Pendahuluan}

Perubahan teknologi yang semakin berkembang telah menghasilkan berbagai jasa serta fasilitasnya dibidang teknologi informasi dan komunikasi. Salah satu fasilitas yang lahir dari transformasi teknologi ini adalah internet. Internet tercipta dari inovasi manusia yang berkeinginan memudahkan komunikasi dalam aspek kesehatan serta militer. Dewasa ini internet menjadi hal terpenting disetiap pemenuhan kebutuhan manusia. Kehadiran internet ini dapat dikatakan mengubah dunia. Melalui internet, kegiatan manusia yang terhalang jarak dan waktu seakan lenyap. Di masa kini, segala sesuatu dapat digapai dengan mudah, cepat, dan juga murah hanya dengan perangkat digital.

Salah satu aspek yang terdampak dari penggunaan internet adalah ekonomi. Kebangkitan teknologi informasi yang menghasilkan internet membuat kegiatan ekonomipun berkembang, dari konvensional menjadi digital. Kebangkitan ekonomi digital ini tidak lepas dari inovasi internet dan revolusi industri 4.0. Revolusi industri 4.0 merupakan pembaruan dari beberapa revolusi sebelumny. Ketika revolusi industri 1.0 yang terjadi pada awal abad 18 menggunakan air dan uap sebagai penggeraknya, serta revolusi industri 2.0 dan 3.0 pada awal 20 menggunakan listrik sebagai motor penggerak proses produksi, revolusi industri 4.0 menggunakan sistem internet sebagai penggeraknya. Revolusi ini menghubungkan antara mesin industri dengan internet, atau dikenal dengan sebutan cybersystem. Cybersystem mengubah pergerakan industri yang awalnya konvesional menjadi digital. Pergeseran ini yang telah melahirkan sebutan ekonomi digital. Salah satu contoh dari produk ekonomi digital adalah Global Over The Top Player seperti Google, induk dari Youtube.

Ekonomi digital ini berpengaruh signifikan pada perekonomian suatu negara. Perkembangan Global Over The Top secara langsung dan tidak langsung menstimulus para penggunanya untuk berinovasi terutama dibidang ekonomi. Inovasi pada bidang ekonomi ini berdampak pada pendapatan ditiap wilayah. Hasil produksi diberbagai 
tempat baik didesa maupun dikota dapat terdistribusikan dengan baik. Selain itu inovasi lain melahirkan berbagai jasa fasilitas yang mendukung pembayaran sehingga dapat diakses lebih mudah, dimana saja, serta kapan saja. Hal ini tentunya berdampak positif bagi pemasukan negara karena perputaran capital yang semakin cepat.

Youtube sebagai salah satu dari produk digitalisasi menjadi wadah yang dicari berbagai kalangan untuk mendapatkan berbagai sumber informasi dan hiburan dengan cepat dan mudah. Sebagai contoh, jika dibandingakan dengan membaca berbagai buku maupun literarur lainnya, masyarakat kini cenderung lebih memilih untuk menonton berbagai konten yang dianggap dapat memenuhi informasinya.

Sebagai situs penyedia bebagai macam konten video, kehadiran YouTube menggeser media massa lainnya. Hal ini mendorong pencinta YouTube berkreasi, bukan hanya sebagai penonton tapi juga menciptakan hal baru yang layak untuk dibagikan. Berawal dari hobi dan kesenangan membagikan pengalaman lewat video, beberapa content creator ini menjadikan YouTube sebagai lahan mendulang pundipundi uang. Youtuber adalah sebutan untuk profesi yang menciptakan ide dan dituangkan menjadi sebuah konten pada kanal Youtube. Konten tersebut dapat berupa suara, tulisan, gambar, maupun gabungan dari beberapa materi yang dikemas menjadi satu video dan diunggah lewat akun pengguna.

Para pengguna YouTube dapat menonton semua jenis video tanpa biaya. Begitu pula dengan pengunggah video. Selain tidak mengeluarkan biaya pada saat membagikan video ke YouTube, YouTuber pun medapatkan imbalan dari video yang diunggahnya. Youtuber tidak serta merta menunggah video, tetapi harus mengikuti persyaratan yang dibuat Youtube. Dengan mengikuti aturan dan persyaratan tersebut, Youtuber akan dapat menghasilkan uang lewat konten yang dimilikinya tersebut.

YouTuber mendapatkan sumber penghasilan yang menjanjikan dari media digital ini. Penghasilan ini tentunya berdasarkan berbagai ketentuan yang telah ditetapkan pihak Google selaku pemilik YouTube. Jika seorang YouTuber telah memilki subscriber atau pengikut diatas atau sama dengan ketentuan dari Google maka penghasilannya pun akan meningkat. Terlebih jika sebuah content yang diunggahnya mendapatkan apresiasi atau likes dan komentar yang positif. Komentar dan Likes ini akan menaikkan peringkat atau ratting dari content tersebut dan hal ini berpengaruh pada komisi yang akan diterima sang pengunggah.

Agar konten mendapatkan penghasilan dari iklan atau Adsense, Youtuber harus mengajukan Program Partner Youtuber (PPY) sebagai langkah awal monetisasi atau registrasi Adsense. Persyaratan pembuatan PPY adalah sebagai berikut, (1) Tinggal diwilayah tempat program partner Youtube tersedia., (2) jumlah minimal pelanggan atau subscriber dalam akun tersebut adalah 1000, (3) Youtuber harus mempunyai akun yang dapat ditautkan pada tautan http://support.google.com/adsense/answer, (4) jumlah jam penayangan yang telah ditonton pengguna lain selama kurun waktu dua belas bulan terakhir adalah 4000 jam. Jika Youtuber belum memenuhi keempat persyaratan tersebut maka Youtuber belum mendapatakan fasilitas Adsense. Sebaliknya jika akun tersebut telah memenuhi syarat tersebut maka pemilik konten berhak mendapatkan fasilitas 
Adsense dan mendapatkanpenghasilan yang dibayarkan Google Asia Pasific sebagai Program Partner Youtube Indonesia melalui western union atau rekening bank.

Cara perhitungan dengan kasar dapat dilakukan dengan megacu pada pendapatan 1 dolar pada setiap 1000 jumlah yang menonton konten tersebut. Seperti contoh Ria Ricis, channelnya yang diberi nama Ricis Official sudah dimulai sejak tahun 2019 dan telah diikuti 12 juta subscriber. Menurut website penghitung penghasilan dengan perkiraan atau Socialblade, penghasilan Ria Ricis dari YouTube diperkirakan sekitar diatas Rp 156.000.000 sebulan dengan kurs dolar Rp 13.000 bahkan dalam berbagai wawancaranya dikompas Ria Ricis dapat mengantongi Rp 1,8 miliar hingga Rp 43 miliar per tahun. Dari keterangan tersebut dapat disimpulkan penghasilan yang diterima YouTuber sangat memungkinkan dikenakan pajak, pasalnya penghasilan tersebut sudah melebihi batas penghasilan kena pajak yang ditetapkan Undang Undang Nomor 36 Tahun 2008. Hal tersebut dapat disimpulkan jika pendapatan Youtuber tersebut dikonversi dengan mata uang Indonesia atau rupiah dengan kurs kementerian keuangan.

Dengan adanya fakta yang telah dipaparkan diatas membuat pemerintah telah seharusnya memanfaatkan peluang ini untuk meningkatkan pemasukan negara. Hal ini menjelaskan bahwa besaran pajak yang timbul dari penghasilan yang diperoleh dari Youtube sangat besar. Walaupun demikian belum ada kebijakan khusus yang mengatur pengenaan patelah digunakan umu untuk seluruh penghasilan di Indonesia.

Disaat penghasilan beberapa YouTuber jauh melebihi batas Penghasilan Kena Pajak, tidak sesuai dengan penerimaan pajak negara yang hampir tidak pernah memenuhi target. Sesuai dengan latar permasalahan tersebut mendorong penulis untuk membuat karya tulis dalam bentuk tesis dengan judul, "Analisis Strategi Pemerintah Dalam Upaya meningkatkan Kepatuhan Wajib Pajak Youtuber di Indonesia”.

Berangkat dari permasalahan umum yang telah dihadapi dunia mengenai stateless revenue terserbut, penghasilan Youtuber satu dari sekian profesi di era digitalisasi ini juga kearap kali menjadi sorotan khususnya pada kewajiban perpajakannya. Penelitian ini bertujuan untuk mengetahui dan memahami bagaimana penerapan pemungutan pajak atas penghasilan yang didapatkan Youtuber beserta strategi yang digunakan pemerintah guna meningkatkan kepatuhan Youtuber sebagai wajib pajak. Hal ini mengacu pada tarif yang ditetapkan pada Undang Undang Nomor 36 Tahun 2008 yang menjelaskan mengenai pajak penghasilan. Selain itu penelitian ini juga bertujuan untuk mengetahui peranan pemerintah dalam menerpakan Undang Undang Nomor 36 Tahun 2008 tersebut.

Undang Undang Nomor 36 Tahun 2008 menyebutkan bahwa objek pajak penghasilan adalah setiap tambahan kemampuan ekonomis yang dterima maupun diperoleh para wajib pajak, baik yang berasal dari Indonesia maupun luar Indonesia, yang dapat dipakai atau digunakan untuk konsumsi ataupun untuk menambah kekayaan wajib pajak bersangkutan, dengan sebutan dan dalam bentuk apapun. Berdasarkan penjelasan tersebut maka penghasilan yang diterima atau diperoleh oleh Youtuber termasuk objek pajak dan wajib dikenakan pajak sesuai dengan ketentuan Undang 
Undang. Dengan demikian pemerintah memiliki peran penting sebagi pengawas dalam perpajakan Youtuber di Indonesia.

Pemerintah sangat berperan penting dalam implementasi kebijakan perpajakan atas Youtuber. Peran pemerintah selain sebagai pengawas juga dibutuhkan untuk mengajarkan, menjelaskan atau sosialisasi setiap peraturan perundang undangan kepada masyarakat. Hal ini dilakukan agar masyarkat mengetahui dan memahami setiap peraturan yang berlaku. Dengan demikian akan timbul kepatuhan dari diri sendiri untuk memnuhi kewajiban perpajakannya. Selain itu diperlukan adanya kepastian hukum agar masyarakat tidak bingung terhadap peraturan tersebut. Kepastian hukum meliputi pembaharuan siring berjalannya waktu untuk menyesuaikan dengan perkembangan yang ada. Jika terdapat ketidaksesuaian dalam penerimaan pajak, pemerintah mempunyai wewenang dalam hal menetapkan kembali kebijakan perpajakan tersebut.

Berbeda dengan Indonesia untuk mengatasi dampak dari perkembangan digitalasiasi ini khususnya Youtube, Amerika telah menerapkan program komputer yang terintegrasi dengan metode dan sistem perpajakan untuk memudahkan Wajib Pajak melaporkan kewajibannya. Jika di Youtuber di Indonesia kesulitan mengetahui besaran pendapatannya, lain halnya di negara ini. Di Amerika terdapat Formulir 1099 yang dapat diunduh pada halaman google jika akun tersebut terdaftar dengan akun asal Amerika. Formulir 1099 ini harus disertakan pada saat pelaporan pajak.

Pada negara berkembang seperti Nigeria, penghindaran pajak dengan berbagai alasan seperti korupsi dan penyelewengan dana telah lazim ditemukan. Youtuber sebagai salah satu profesi yang menjanjikan menjadi primadona baru dalam target penerimaan negara. Karena itu Nigeria mempunyai strategi sendiri untuk mencegah ketidakpedulian masyarakatnya khususnya Youtuber dalam membayar pajak. Strategi tersebut dengan merekomendasikan selebriti menjadi duta pajak yang membawa kesan baik dikalangan masyarakat. Hal ini juga dilakukan oleh Korea Selatan. Pasalnya masyarakat mempunyai ketertarikan sendiri terhadap para selebriti dibanding aparat negara atau pihak administrasi. Dengan dipromosikan oleh selebriti maka tingkat kepatuhanpun meningkat.

Berangkat dari latar belakang yang telah dipaparkan, diperlukan beberapa teori dan konsep yang mendukung penelitian ini. Hadirnya profesi Youtuber tidak lepas dari kemajuan dari teknologi informasi. Teknologi Informasi merupakan keseluruhan dari rangkaian bentuk teknologi yang digunakan untuk menciptakan data, mengubahnya, dan menggunkananya menjadi suatu informasi dalam seluruh bentukannya, (Munir \& IT, 2009). Menurut Bambang (Warsita, 2008), teknologi merupakan sarana dan juga prasarana yang meliputi software, hardware, serta useware. Teknologi juga meliputi sistem serta metode untuk memperoleh, mengolah, mengirim, menafsirkan, menyimpan, mengorganisasikan, serta menggunakan data dengan bermakna, (Prasojo \& Riyanto, 2011). Sedangkan menurut (Lamatenggo \& Uno, 2016), teknologi informasi dan komunikasi adalah segala kegiatan yang dilakukan untuk mendukung record, penyimpanan, proses, mendapatkan lagi, mengantarkan, dan menerima informasi. Kemajuan teknologi membawa peranan besar dalam perubahan dunia. 
Perubahan yang disebabkan kemajuan teknologi ini meliputi banyak hal, seperti ekonomi. Perkawinan ekonomi dengan kemajuan teknologi menghasilkan ekonomi digital. Ekonomi digital merupakan aspek ekonomi yang memanfaatkan serta memberdayakan teknologi informasi dan komunikasi digital. (Hartman, Kador, \& Sifonis, 2000) "the virtual arena in which business actually is conducted, value is created and exchanged, transaction occur, and one-to-one relationship mature by using any internet initiative as medium of exchange". Pertumbuhan ekonomi digital didasari oleh perkembangan kereatifitas, bisnis dan transaksi perdagangan dengan menggunakan internet sebagai media utama komunikasi dan berkolaborasi antar perusahaan ataupun antar individu. Menurut Don Tapscott (Tapscott, 1996), ekonomi digital adalah fenomena social yang memengaruhi sistem ekonomi. Fenomena tersebut mempunyai ciri-ciri sebagai suatu ruang intelijen yang terdiri dari informasi. Komponen dari ekonomi digital yaitu e-commerce, distribusi digital barang, dan industri teknologi informasi dan komunikasi.

Dengan lahirnya Youtube terdapat profesi baru yang dikenal sebagai Youtuber. Berbicara mengenai profesi dan penghasilan yang didapatkan berarti ada kewajiban perpajakan didalamnya. Sebagai salah satu negara yang menganut self assessment, membuat Indonesia bergantung pada kesadaran dan kepatuhan wajib pajaknya dalam pencapaian target penerimaan perpajakannya. Menurut (Kurnia, 2010) dan (Rahayu, 2019) mengatakan, "Kepatuhan memenuhi kewajiban perpajakan yang dilakukan secara sukarela merupakan tulang punggung sistem self assessment, dimana wajib pajak bertanggung jawab menetapkan sendiri kewajiban perpajakan dan kemudian secara akurat dan tepat waktu membayar dan melaporkan pajakanya tersebut”.

Menurut (Tahar \& Rachman, 2014) Kepatuhan mempunyai arti ketaatan terhadap perintah atau aturan. Terdapat beberapa teori yang memuat mengenai kepatuhan. Kepatuhan atas kewajiban perpajakan merupakan sebuah tanggung jawab antar manusia kepada Tuhan. Bagi pemerintah dan masyarakat sebagai wajib pajak agar dapat memenuhi kewajiban perpajakan juga agar dapat mendapatkan hak perpajakannya. Teori kepatuhan atau Compliance Theory merupakan teori yang menjelakan mengenai kondisi taat dan mengikuti aturan maupun perintah yang diberikan. Perilaku kepatuhan pada wajib pajak didorong oleh kesadaran wajib pajak atas kewajibannya yang dalam hal ini sebagai perintah dari pemerintah dengan tetap mengacu kepada peraturan perundang undangan yang sudah ditetapkan.

Strategi yang dibahas pada penelitian ini berkaitan dengan strategi peningkatan tingkat kepatuhan wajib pajak dalam pemenuhan kewajiban perpajakannya. Setiap organisasi publik memiliki tanggung jawab untuk melayani masyarakat untuk tetap hidup dan berkembang untuk dapat menyesuaikan diri dengan berbagai situasi yang terus berubah begitu pula dengan perpajakan. Mintzberg menyatakan jika strategi sesungguhnya tidak memiliki teori yang pasti “....We offer no such easy definition here. Instead we arguethat strategy requires a number of definition, five in particular...", (Mintzberg, Ahlstrand, Lampel, \& Safari, 1998). Mintzberg pun menyatakan bahwa strategi membutuhkan sejumlah tafsiran. Terdapat lima tafsiran atau definisi dari 
strategi yaitu, perspektif, posisi, perencanaan, pola kegiatan, dan juga pola penipuan. Sedangakn perencanaan strategi merupakan proses yang berulang (Strategy Change Cycle), "Strategy Change Cycle was designed specifically to help and nonprofit organization (and communities) think, act, and learn strategically", (Bryson \& Alston, 2010). Strategy Change Cycle dirancang secara spesifik untuk membantu publik dan organisasi non-profit dalam berpikir, bertindak, dan belajar secara stratejik. Strategy Change Cycle merupakan gagasan dari sebuah proses strategi, model proses pengambilan keputusan, atau pandangan aktivitas yang berdasarkan strategi. Pemimpin organisasi mengatur kegiatan utama dalam proses perencanaan namun memberikan berbagai strategi individual kepada yang lainnya. Strategy Change Cycle merupakan sebuah proses manajemen strategi, bukan hanya proses perencanaan strategi.

Menurut (Rahayu, 2019) tuntutan terhadap penerimaan negara dari sektor pajak merupakan strategi penesuaian struktur perpajakan dan stabilisasi ekonomi dengan kebijakan fiskal. Terdapat dua pengertian kebijakan fiskal menurut menurut (Mansury, 1999), pengertian tersebut mencakup pengertian luas dan pengertian sempit. Pengertian luas pada kebijakan fiskal adalah kebijakan untuk memengaruhi produksi, mengatur kesempatan bekerja, dan mengatur inflasi mata uang dengan merujuk dari instrument pemungutan pajak serta pengeluaran Negara guna mencapai tujuan Negara. Sedangkan pengertian sempit dari kebijakan fiskal adalah kebijakan yang menentukan siapa yang berkewajiban dikenakan pajak, apa yang dijadikan dasar pengenaan pajak tersebut, dan bagaimana menghitung besarnya pajak yang harus dibayarkan beserta aturan pembayaran pajak terutang. Menurut (Rosdiana \& Tarigan, 2005), Kebijakan Pajak merupakan artian sempit dari Kebijakan Fiskal. Kebijakan pajak merupakan bagian dari kebijakan fiskal. Hal ini merupakan sebab dilakukan strategi kebijakan yang membuat suatu perubahan dalam perpajakan. Strategi ini dapat dikatakan berhasil jika membuat perubahan signifikan. Pada sistem perpajakan terdapat elemen yang saling berkaitan dalam memengaruhi perubahan yaitu institusi yang mengatur administrasi serta kepatuhan pajak dan struktur mekanisme kebijakan perpajakan.

Menurut (Gunadi, 2013), formulasi kebijakan perpajakan yang baik sekalipun mungkin saja dapat tidak mencapai target dengan sukses disebabkan oleh kepatuhan. Hal ini disebabkan tidak mampunya administrator melakukannya. Gunadi imengatakan, "administrasi perpajakan dituntut bersifat dinamik sebagai upaya peningkatan penerapan kebijakan perpajakan yang efektif. Kriteria fisibilitas administrasi menuntut agar sistem pajak baru meminimalisir biaya administrasi (administrative cost) dan biaya kepatuhan (compliance cost) serta menjadikan administrasi pajak sebagai bagian dari kebijakan pajak".

Nasucha dalam (Rahayu, 2019) mengatakan bahwa strategi administrasi perpajakn mempunyai tugas utama yaitu mencapai efektiffitas penerimaan negara yang tertinggi dan efisiensi yang berupa biaya administrasi seminim mungkin. Kedua hal tersebut baik efektifitas dan efisiensi seringkali berbenturan dan membuat kontradiksi. Karena itu diperlukan koordinasi berkesinambungan agar keduanya dapat bersinergi. 
Pada penelitian ini penulis mencoba melakukan beberapa komparasi terhadap penelitian terdahulu terakit penghasilan Youtuber. Peneliti mencari prinsip dan landasan teori terkait dengan perumusan masalah serta mengkaji faktor yang mempengaruhi kebijakan pajak penghasilan Youtuber dan dapat mendukung penelitian mengenai Analisis Strategi Pemerintah Dalam Upaya Meningkatkan Kepatuhan Wajib Pajak Youtuber di Indonesia. Tinjauan pertama sebuah jurnal penelitian yang ditulis oleh (Wijaya \& Mahatma, 2017) yang berjudul Analisa Upaya Peningkatan Penerimaan Perpajakan dari Penggalian Potensi Pajak atas Penghasilan Youtuber. Menurut (Wijaya \& Mahatma, 2017), penghasilan yang didapatkan Youtuber Indonesia belum dapat dikenakan pajak dari pemberi penghasilan, yaitu Google Asia Pasific. Bukti dari ketidakdikenakannya pajak adalah tidak adanya bukti bayar atas konten ataupun bukti pemotongan pajak yang terlampir dalam invoice pembayaran yang diberikan pihak Google kepada Youtuber dan dicairkan lewat rekening bank atau western union.

Penelitian berikutnya adalah Analisis Pelaksanaan Pengawasan Pajak Penghasilan atas Penghasilan Youtuber Pada Direktorat Jenderal Pajak, yang ditulis oleh (Lestari, Nurmantu, \& Vikaliana, 2019). Menurut (Lestari et al., 2019), kebijakan perpajakan atas penghasilan Youtuber tergolong masih buram. Hal ini disebakan masih belum adanya kepastian hukum yang mengatur spesifik atas penghasilan tersebut.

Dari hasil penelitian tersebut, telah dipaparkan mengenai penghasilan Youtuber yang seharusnya menjadi objek pajak tetapi belum ada yang meneliti mengenai strategi kebijakan perpajakannya. Fokus utama dalam penelitian ini adalah strategi pemerintah dalam melakukan kewajiban perpajakan atas penghasilan Youtuber, sehingga penelitian ini akan memberikan hasil yang belum pernah ditemukan sebelumnya. Sebagai sebuah strategi, administrasi perpajakan memerlukan tolak ukur dalam menentukan efketifitas dan efisiensi target penerimaaan. Ukuran dalam meningkatkan efektifitas tersebut antara lain (1) prinisp self assesment, (2) kecepatan penemuan masalah terkait surat pemberitahuan atau SPT, (3) peningkatan kualitas kontrol supervisi dalam administrasi, (4) penyediaan informasi terkait kebijakan perpajakan kepada wajib pajak, (5) kepatuhan wajib pajak, (6) sanksi tegas bagi wajib pajak yang melanggar. Sehingga hasil penelitian ini akan menjelaskan bagaimana strategi yang dilakukan pemerintah dan faktor apa saja yang memengaruhi kesadaran perpajakan Youtuber di Indonesia.

\section{Metode Penelitian}

Penelitian ini menggunakan paradigma post-positivisme. Penggunaan paradigma tersebut didasarkan pada pengembangan pertanyaan penelitian yang mempengaruhi tahapan berikutnya. positivisme. Salah satu hal yang menjadi ciri paradigma postpositivisme adalah menggunakan teori sebagai acuan memahami permasalahan penelitian sampai dengan membuat definisi operasional. Selain adanya acuan pada teori, paradigma post-positivisme dicirikan dengan adanya hubungan yang erat antara peneliti dengan obyek yang diteliti sehingga dalam paradigma ini subyek tidak mungkin dapat melihat kebenaran jika pengamatan dilakukan dibelakang layar tanpa ikut terlibat dengan obyek secara langsung sehingga hubungan antara pengamat 
Pendekatan penelitian yang digunakan dalam proses penelitian ini adalah pendekatan kualitatif. Peneliti mencoba mengangkat permasalahan dengan pendekatan kualitatif dengan tujuan untuk mengembangkan teori yang digunakan dalam penelitian ini. Penelitian melalui pendekatan kualitatif memberikan suatu pemahaman yang mendalam karena memepertanyakan makna suatu objek secara mendalam dan tuntas

\section{Hasil dan Pembahasan}

\section{A. Analisis Strategi Direktorat Jenderal Pajak Dalam Meningkatkan Kepatuhan Wajib Pajak Youtuber di Indonesia}

Indonesia merupakan salah satu negara yang menganut sistem self assessment pada regulasi pemajakannya. Hal ini menjadi acuan para otoritas pajak dalam pemenuhan target perpajakannya. Pasalnya penerimaan pajak sangat bergatung pada pembayaran pajak yang didasari kesadaran dari diri wajib pajak. Pelaku usaha Youtuber, Oskar Mahendra berpendapat regulasi perhitungan penghasilan sampai dengan pemajakan atas penghasilan Youtuber yang belum jelas dan masih banyak pegawai pajak yang belum memahami mengenai pemajakan atas penghasilan youtuber. perlu adaptasi bagi pegawai yang belum memahami pemajakan atas penghasilan youtuber, hubungannya dengan penerimaan negara dan peluang penghindaran pajaknya. Dan diperlukan pula inovasi baik bagi metode pelatihan dan transfer knowledge antar pegawai DJP, ke Wajib Pajak dan pihak lain terkait hal tersebut, berikut kutipan interview dengan Oskar Mahendra,

"Menurut saya sangat sulit memenuhi kewajiban perpajakan atas penghasilan saya sebagai seorang Youtuber. Bagi saya youtube adalah wadah saya mencurahkan hobi saya, dan penghasilan yang saya dapat dari konten yang saya buat tidak pasti setiap bulannya. Saya dan juga rekan sesame youtuber tidak pernah secara langsung diberi arahan soal pajak oleh petugas pajak. Tidak ada kepastian besaran penghasilan yang saya dapatkan serta minimnya edukasi dari orang pajak (DJP). Mungkin dapat diawali dari pegawai pajaknya. Edukasi sangat perlu bagi pegawai dan institusi DJP karena saya yakin mereka pun banyak yang belum bisa menjawab dengan jelas mengenai perpajakan atas penghasilan Youtuber ini, jika sudah jelas dari segala aspek menurut saya bukan hal yg sulit memonitor pelaksanaan karena sifatnya digital sehingga data mudah diolah. Pajak atas penghasilan Youtuber bisa merupakan ancaman besar bagi kondisi revenue pajak negara jika tidak disiapkan dengan baik. Hal yang paling mendasar adalah adanya landasan hukum perpajakan yang jelas dan terperinci untuk jenis industri, kategori dan hal lainnya yg berhubungan."

Strategi pembuatan tim pada KPP Senen merupakan langkah para otoritas pajak dalam menerapkan pengawasan pada kemajuan ekonomi digital saat ini. Kekurangan data dan pengembangan aplikasi mejadi tugas utama yang dihadapi para fiskus dilapanagan. Adapun terkait pengembangan aplikasi dan sistem informasi, peneliti melakukan wawancara dengan Key Informant yaitu Eka 
Darmayanti, Kepala Sub Direktorat Tata Kelola Sistem Data dan Informasi, Direktorat Teknologi dan Informasi Perpajakan, yang menjelaskan bahwa,

"Saat ini sedang dibangun aplikasi untuk mengakomodir kebutuhan terkait pemajakan ekonomi digital. Dalam jangka panjang, selain akan membuat aplikasi pemenuhan kewajiban perpajakan bagi end user (WP), DJP juga membangun aplikasi yang akan digunakan untuk melakukan pengawasan dan penegakan hukum atas pemenuhan kewajiban perpajakan ekonomi digital. DJP juga membuka ruang untuk melakukan kolaborasi dengan pihak eksternal terutama dengan ekosistem pembayaran (bank, payment gateway) dan penyedia jasa aplikasi perpajakan (PJAP)."

Dijelaskan oleh Eka Darmayanti bahwa DJP melakukan beberapa hal terkait aplikasi dan sistem informasi yang sedang dibangun dan dikembangkan oleh DJP, karena ini yang benar-benar urgent diperlukan sekarang ini dan segera untuk memajaki ekonomi digital. Sementara program jangka panjang yaitu mengembangkan aplikasi pemenuhan kewajiban perpajakan bagi Wajib Pajak, pengawasan dan penegakan hukum atas pemenuhan kewajiban perpajakan dan membuka ruang kolaborasi dengan instansi/lembaga/pihak eksternal terkait sistem pembayaran dan penyedia jasa aplikasi lebih kepada keyakinan bahwa perubahan itu memerluka mekanisme untuk dapat mencapai tujuan yaitu memajaki sektor ekonomi digital dengan baik.

Pengembangan layanan digital menjadi bagian utama dalam meningkatkan kesadaran wajib pajak youtuber di Indonesia. Menghadapi kemajuan teknologi yang semakin pesat dan berdampak pada pertumbuhan ekonomi digital khususnya youtube, Direktorat Jenderal Pajak selaku pemerintah membuat Sembilan Rencana Strategis DJP khususnya untuk menghadapi digitalisasi. Sembilan Rencana Strategi DJP tersebut dijabarkan pada tabel 1 sebagai berikut.

Tabel 1

Rencana Strategis DJP Periode 2020 - 2024

\begin{tabular}{lll}
\hline No & \multicolumn{1}{c}{$\begin{array}{c}\text { Rencana Strategis (RenStra) DJP } \\
\text { Periode 2020 - 2024 }\end{array}$} & Hasil \\
\hline 1 & $\begin{array}{l}\text { Pengembangan Sistem Click, Call, Counter } \\
(3 \mathrm{C})\end{array}$ & Belum Terlaksana \\
\hline \multirow{2}{*}{$\begin{array}{l}\text { Integrasi Digital Tax Knowledge Based } \\
\text { dengan situs web DJP }\end{array}$} & $\begin{array}{l}\text { Keputusan Direktorat Jenderal Pajak } \\
\text { Nomor KEP-317/PJ/2020 tentang } \\
\text { Penunjukan PT Fintek Integrasi Digital } \\
\text { Sebagai Penyedia Jasa Aplikasi Perpajakan } \\
\text { yang Memberi Edukasi Perpajakan Lewat } \\
\end{array}$ & $\begin{array}{l}\text { Media Sosial serta Layanan } \\
\text { Menyelenggarakan Penyaluran SPT Dalam } \\
\text { Bentuk Dokumen Elektronik }\end{array}$ \\
\hline \multirow{2}{*}{$\begin{array}{l}\text { Pengembangan Layanan Edukasi Pajak } \\
\text { pada wajib pajak Youtuber }\end{array}$} & Belum Terlaksana \\
\hline
\end{tabular}




\begin{tabular}{|c|c|c|}
\hline No & $\begin{array}{c}\text { Rencana Strategis (RenStra) DJP } \\
\text { Periode } 2020 \text { - } 2024\end{array}$ & Hasil \\
\hline 4 & $\begin{array}{l}\text { Pengembangan Program Inklusi Perpajakan } \\
\text { DJP }\end{array}$ & $\begin{array}{l}\text { Pembuatan Pajak Bertutur, DJP } \\
\text { High School Tax Road Show, High School } \\
\text { Tax Competition, dan Tax Goes } \\
\text { to Campus. Semua kegiatan ini } \\
\text { memunculkan semangat yang berkesan } \\
\text { bagi kalangan pelajar-mahasiswa dalam } \\
\text { menanamkan kesadaran pajak sejak dini }\end{array}$ \\
\hline 5 & $\begin{array}{l}\text { Pengembangan Edukasi melalui pihak } \\
\text { ketiga }\end{array}$ & $\begin{array}{l}\text { Pengembangan berbagai Tax Center yang } \\
\text { dapat memperkecil ketidakpatuhan wajib } \\
\text { pajak khususnya pada sektor ekonomi } \\
\text { digital }\end{array}$ \\
\hline 6 & Pengembangan Sarana Kehumasan & $\begin{array}{l}\text { Pengembangan Kehumasan DJP dengan } \\
\text { komunikasi dan edukasi lewat media sosial }\end{array}$ \\
\hline 7 & Perluasan Prepopulated SPT PPh & Belum Terlaksana \\
\hline 8 & Perluasan Kanal Pembayaran Pajak & $\begin{array}{l}\text { Bekerja sama dengan Fintek dan } \\
\text { Eccommerce dalam memudahkan } \\
\text { pembayaran pajak }\end{array}$ \\
\hline 9 & $\begin{array}{l}\text { Automasi Penelitian Restitusi Wajib Pajak } \\
\text { Youtuber }\end{array}$ & Belum Terlaksana \\
\hline
\end{tabular}

Sumber: Direktorat Jenderal Pajak, Diolah oleh Peneliti

Berdasarkan Rencana Strategis Direktorat Jenderal Pajak Periode 2020 2024 tersebut, peneliti menganalisis bahwa pemerintah dalam hal ini Direktorat Jenderal Pajak telah berupaya membuat program menghadapai kemajuan ekonomi digital khususnya youtuber. Sebagian dari sembilan rencana strategi tersebut telah berjalan dengan baik, tetapi beberapa belum terlaksana tau masih dalam tahap pengembangan. Perencanaan strategi Sistem Click, Call, Counter (3C) masih dalam tahap pengembangan. Begitupun dengan Layanan Edukasi Pajak pada wajib pajak Youtuber, Perluasan Prepopulated SPT PPh, Automasi Penelitian Restitusi Wajib Pajak Youtuber masih dalam proses pengembangan.

Beberapa dari rencana strategis tersebut telah berjalan, salah satunya adalah Pengembangan Sarana Kehumasan. Kehumasan Direktorat Jenderal Pajak berupaya berkomunikasi dengan wajib pajak dalam hal ini selebgram atau youtuber dengan membuat akun dan kanal media sosial dan aktif berperan membagikan informasi terdepan dan terpercaya dengan tujuan membangun kesadaran wajib pajak di era digitalisasi ini.

Faktor sanksi kepada wajib pajak youtuber yang lalai dalam menjalankan kewajibannya juga bisa memberikan pengaruh tersendiri bagi wajib pajak. Di dalam undang-undang perpajakan, dikenal dua macam sanksi yaitu sanksi administratif dan sanksi pidana. Sanksi administratif adalah pembayaran kerugian kepada negara, 
khususnya berupa bunga dan kenaikan. Sedangkan sanksi pidana merupakan siksaan atau penderitaan. Merupakan suatu alat terakhir atau benteng hukum yang digunakan fiskus agar norma perpajakan dipatuhi. Dengan adanya sanksi, diharapkan para wajib pajak bisa lebih patuh dalam membayar utang pajaknya. Dalam hal ini, peneliti melakukan wawancara kepada key informan youtuber lainnya, Jordan Andreas.

"Penghasilan yang saya dapatkan dari kanal youtube tidak pasti. Jika ingin mendapatkan penghasilan yang banyak, harus konsisten mengunggah konten. Jika sudah dapat penghasilan, jujur saya belum pernah membayar pajaknya. Sampai saat ini saya tidak tahu jelas akan sanksi yang dikenakan jika tidak membayar pajak atas penghasilan dari youtube ini. Karena belum ada aturan yang jelas jadi tidak kepikiran untuk bayar pajak. Jika sudah ada aturannya, saya yakin akan bagus. Dan sebagai youtuber saya akan membayar pajak sesuai dengan ketentuan."

Tingkat ketaatan wajib pajak dalam melaporkan kewajibannya masih tergolong rendah terutama di kalangan penggiat media sosial. Dalam konteks ini maupun youtuber. Walaupun belum ada regulasi yang tepat mengenai pajak atas penghasilan youtuber ini Direktorat Jenderal Pajak tetap melakukan sosialisasi dan pengawasan kepada para selebriti dan juga youtuber untuk meningkatkan kepatuhannya. Pasalnya penghasilan yang dihasilkan youtuber dapat dilaporkan sebagai penghasilan bebas. Seperti yang dikatakan oleh Andri Budiman, sebagai Pelaksana Direktorat Potensi Kepatuhan dan Penerimaan Direktorat Jenderal Pajaka.

"Ketentuan pajak atas penghasilan youtuber termasuk dalam ketentuan pajak penghasilan UU No. 36 Tahun 2008. Karena itu pelaporan pajak bagi youtuber sangat mudah dan sama dengan wajib pajak lainnya. Begitu pula jika tidak melaporkan maka akan dikenakan sanksi. Sanksinya, kalau tidak lapor SPT Tahunan denda Rp 100 ribu. Kalau ada pajak yang terutang dan tidak dibayar, kena sanksi bunga $2 \%$ per bulan. Sama persis dengan wajib pajak atas penghasilan lainnya. Untuk mengawasi penerimaan pajak dari youtuber ini, Direktorat Jenderal Pajak (DJP) Kementerian Keuangan (Kemenkeu) telah memiliki sebuah sistem bernama Social Network Analytics (SONETA). SONETA ini bertugas menganalisis penyandingan data baik untuk pajak penghasilan $(\mathrm{PPh})$ maupun pajak pertambahan nilai (PPN). Data ini Diuji dengan data-data yang kita miliki, baik data internal maupun data-data yg diperoleh dari eksternal seperti instansi, lembaga, asosiasi dan pihak lain"

Menurut analisis peneliti, strategi pengenaan sanksi pada wajib pajak youtuber belum efektif meningkatkan kepatuhan youtuber dalam menjalankan kepatuhan perpajakannya. Belum ada perhitingan yang jelas serta belum ada regulasi terkait kebijakan perpajakan atas penghasilan youtube menjadi alasan utama sulitnya meningkatkan kepatuhan wajib pajak youtuber. Akan tetapi beberapa strategi sudah dijalankan oleh otoritas pajak Indonesia dalam menyaring target yang akan diberikan sanksi atas kelalaian dari pemenuhan kewajiban perpajakannya. Seperti membentuk SONETA. Hasilnya akan dianalisis dan diberi pendekatan 
sampai dengan pemberian sanksi administratif, denda, sampai dengan bunga. Tetapi strategi yang nantinya akan dilakukan adalah, penutupan kanal youtube dari Youtuber yang tidak patuj membayar pajak. Tetapi sampai saat ini belum diberlaukan. Jika strategi ini diberlakukan, mungkin akan membuat efek jera bagi para youtuber yang tdak membayar pajak. Pasalnya youtuber akan kehilangan video hasil unggahannya dan akan sulit membuka akun baru para sosial media tersebut. Sanksi ini mungkin akan lebih dikhawatirkan para youtuber dibanding denda atau bunga seperti denda kelalaian pajak penghasilan lainnya.

Demi terwujudnya realisasi penerimaan pajak yang maksimal khususnya dari pernghasilan youtuber diperlukan berbagai strategi, yaitu selain dengan pengetahuan perpajakan yang dimiliki oleh wajib pajak itu sendiri, salah satu upaya yang dapat dilakukan adalah dengan memberikan pelayanan yang baik kepada wajib pajak youtuber. Namun kenyataannya, masih ada wajib pajak yang menemukan hambatan dalam prosespelayanan yang diberikan oleh aparatur perpajakan, seperti petugas yang lambat, tidak ramah, berbelit-belit, serta keadaan kantor dan layanan yang kurang nyaman, sehingga menimbulkan berbagai keluhan, dan pada akhirnya berakibat pada tumbuhnya sikap tidak patuh dalam melaksanakan kewajiban perpajakan Seperti yang dikatakan key informant, DJP telah berupaya menjalankan strategi internal dalam meningkatkan kualitas dan kuantitasnya demi menghadapi kemajuan ekonomi digitalisasi. Adapun berbagai strategi yang telah dijalankan, dijabarkan sebagai berikut.

\section{Tabel 2}

Strategi Direktorat Jenderal Pajak dalam meningkatkan Kualitas dan Kuantitas Fiskus

\begin{tabular}{|c|c|c|}
\hline No & $\begin{array}{l}\text { Strategi Direktorat Jenderal } \\
\text { Pajak dalam meningkatkan } \\
\text { Kualitas dan Kuantitas Fiskus }\end{array}$ & Keterangan \\
\hline 1 & $\begin{array}{l}\text { Strategi Desain Pendidikan dan } \\
\text { Pelatihan atas Ekonomi Digital }\end{array}$ & $\begin{array}{l}\text { Membentuk TIM Kerja beranggotakan perwakilan } \\
\text { seluruh Direktorat Kantor Pusat DJP yang } \\
\text { bersama-sama dengan Pusdiklat Pajak melakukan } \\
\text { review dan menyusun Desain Pendidikan dan } \\
\text { Pelatihan termasuk mengenai Ekonomi Digital } \\
\text { agar mampu memenuhi standar kompetensi yang } \\
\text { dibutuhkan oleh DJP }\end{array}$ \\
\hline 2 & Training Needs Analysis (TNA) & $\begin{array}{l}\text { Penyelenggaraan kegiatan TNA yang } \\
\text { dilaksanakan oleh Widyaiswara dan struktural } \\
\text { Pusdiklat Pajak. Output kegiatan TNA tersebut } \\
\text { dipadukan dengan hasil TNA yang dilaksanakan } \\
\text { oleh TIM dari DJP dan diharapkan melalui } \\
\text { kegiatan tersebut dapat menjadi blue print } \\
\text { pengembangan SDM DJP melalui diklat, di saat } \\
\text { ini dan yang akan datang. }\end{array}$ \\
\hline
\end{tabular}




\begin{tabular}{lll}
\hline & & Penyesuaian dengan perubahan kebutuhan di DJP \\
& & yaitu diklat berbasis administrasi modern. \\
& Penyelenggaraan diklat diprioritaskan pada \\
& Pemenuhan kebutuhan kantor-kantor pajak \\
& Fiskus & modern yang baru (Diklat Account \\
& & Representative, Diklat Penelaah Keberatan, Diklat \\
& Pelayanan terpadu, Diklat Proses Bisnis Wajib \\
& Pajak, dan lain-lain) \\
\hline & Dalam rangka meningkatkan kualitas fiskus \\
& diperlukan pemetaan masalah yang menjadi \\
& sorotan dilapangan. Dari pemetaan tersebut \\
& diketahui problema-problema yang dapat \\
& Pemetaan Masalah Ekonomi & menghambat perkembangan pusdiklat sehingga \\
& dapat dijadikan instrument dalam menetapkan \\
& langkah-langkah manajemen \\
\hline
\end{tabular}

$5 \quad$ Komunikator Diklat

Untuk menjaring kebutuhan diklat di daerah, Kasi Bimbingan dan Konsultasi pada setiap Kanwil Pajak ditunjuk sebagai komunikator diklat dengan Surat Keputusan Sekretaris DJP.

Forum ini terdiri dari 3 unsur, yaitu Kabid Perencanaan dan Pengembangan, Kabag Kepegawaian DJP, dan Kasubdit Pihak dilaksanakan tiap bulan sekali dengan agenda pembahasan permasalahan diklat berkaitan dengan rencana, penyelenggaraan dan evaluasi pelatihan.

Kegiatan ini bertujuan untuk menajamkan muatan

$7 \quad$ Membudayakan Tradisi Ilmiah materi diklat dan meningkatkan kompetensi dan wawasan.

Sumber: Direktorat Jenderal Pajak, Diolah oleh Peneliti (2020)

Dari hasil wawancara dan informasi yang didapat dilapangan menurut analisis peneliti, strategi peningkatan kepatuhan wajib pajak youtuber ditinjau dari pengembangan kualitas dan kuantitas fiskus sudah berjalan dengan baik. Hanya saja belum ada regulasi yang tepat terkait prosedur pemajakan. Disisi lain DJP dengan pihak lainnya berupaya menigkatkan kualitas SDM guna bersiap akan regulasi yang akan dating. Sejauh ini, kualitas pelayanan dilapangan telah meningkat dari tahun sebelumnya, menandakan upaya yang dilakukan membuahkan hasil peningkatan

\section{Kesimpulan}

Disaat penghasilan beberapa YouTuber jauh melebihi batas Penghasilan Kena Pajak, tidak sesuai dengan penerimaan pajak negara yang hampir tidak pernah memenuhi target. Sudah seharusnya pemerintah melakukan startegi dalam implementasi 
kebijakan perpajakan atas Youtuber. Peran pemerintah selain sebagai pengawas juga dibutuhkan untuk mengajarkan, menjelaskan atau sosialisasi setiap peraturan perundang undangan kepada masyarakat. Hal ini dilakukan agar masyarkat mengetahui dan memahami setiap peraturan yang berlaku

Pada negara berkembang seperti Nigeria, penghindaran pajak dengan berbagai alasan seperti korupsi dan penyelewengan dana telah lazim ditemukan. Youtuber sebagai salah satu profesi yang menjanjikan menjadi primadona baru dalam target penerimaan negara. Karena itu Nigeria mempunyai strategi sendiri untuk mencegah ketidakpedulian masyarakatnya khususnya Youtuber dalam membayar pajak. Strategi tersebut dengan merekomendasikan selebriti menjadi duta pajak yang membawa kesan baik dikalangan masyarakat. Hal ini juga dilakukan oleh Korea Selatan. Pasalnya masyarakat mempunyai ketertarikan sendiri terhadap para selebriti dibanding aparat negara atau pihak administrasi. Dengan dipromosikan oleh selebriti maka tingkat kepatuhanpun meningkat.

Berbeda dengan negara lain, Indonesia lebih mengutamakan strategi pengembangan disisi internal dalam meningkatkan kepatuhan wajib pajak youtuber di Indonesia. Pasalnya belum ada aturan yang spesifik terkait regulasi pemajakan atas penghasilan youtuber. Sejauh ini penghasilan youtuber harus dilaporkan sebagai objek pajak mengikuti peraturan pajak penghasilan pada Undang Undang Nomor 36 Tahun 2008. Strategi tersebut meliputi peningkatan kesadaran ditinjau dari inovasi organisasi pada DJP, strategi peningkatan kepatuhan wajib pajak youtuber ditinjau dari sanksi perpajakan, kualitas dan kuantitas fiskus, serta keadilan bagi wajib pajak youtuber.

Dari teori perpajakan, teori startegi, fakta di lapangan dan pendapat key informant dalam wawancara yang telah dilakukan menganalisis bahwa tingkat kepatuhan wajib pajak youtuber begantung pada persepsi keadilan pajak dipengaruhi oleh kepentingan pribadi (self-interest). Kepentingan pribadi dari youtube merupakan dorongan atau motivasi dari dalam diri wajib pajak yang berhubungan langsung dengan persepsi yang akan mempengaruhi perilaku kepatuhan pajak mereka. Sedangkan untuk strategi peningkatan kepatuhan wajib pajak Youtuber masih harus disempurnakan, seperti perihal kerjasama dengan pihak Google, kurangnya pelibatan pihak eksternal DJP dalam penyusunan regulasi perpajakan dan koordinasi dengan instansi pemerintah dan pihak eksternal lain terkait pemajakan atas ekonomi digital, pengembangan layanan edukasi pajak kepada youtuber secara langsung, dan juga sistem pendukung yang menjamin keakuratan perhitungan penghasilan youtuber, serta transaparansi pungutan pajak terkait perhatian pemerintah guna pengembangan industri content creator di Indonesia . Hal ini disebabkan belum adanya kebijakan yang tepat yang mengatur penghasilan Youtuber. Dengan kata lain, kualitas fiskus, kemudahan sistem serta adil atau tidaknya perpajakan yang berlaku mempengaruhi tingkat kepatuhan pajak wajib pajak youtuber. 


\section{BIBLIOGRAFI}

Bryson, John M., \& Alston, Farnum K. (2010). Creating and implementing your strategic plan: A workbook for public and nonprofit organizations (Vol. 1). Amerika Serikat: John Wiley \& Sons.

Gunadi. (2013). Panduan Komprehensif Pajak Penghasilan. Jakarta: UI Library.

Hartman, Amir, Kador, John Coautor, \& Sifonis, JohnCoautor. (2000). Net Ready: Estrategias para el éxito en la nueva economía. Newyork: McGraw-Hill,.

Kurnia, Siti. (2010). Perpajakan Indonesia: Konsep dan Aspek Formal. Yogyakarta: Graha Ilmu.

Lamatenggo, Nina, \& Uno, Hamzah B. (2016). Teknologi komunikasi \& informasi pembelajaran. Jakarta: Bumi Aksara.

Lestari, Ainul Dian, Nurmantu, Safri, \& Vikaliana, Resista. (2019). Analisis Pelaksanaan Pengawasan Pengenaan Pajak Penghasilan Atas Penghasilan Youtubers Pada Direktorat Jenderal Pajak Tahun 2018. Jurnal Reformasi Administrasi: Jurnal Ilmiah Untuk Mewujudkan Masyarakat Madani, 6(2), 144162.

Mansury, R. (1999). Kebijakan fiskal. Jakarta: YP4.

Mintzberg, Henry, Ahlstrand, Bruce, Lampel, Joseph, \& Safari, Strategy. (1998). A guided tour through the wilds of strategic management. New York: Free Press.

Munir, Dr, \& IT, M. (2009). Pembelajaran jarak jauh berbasis teknologi informasi dan komunikasi. Bandung: Alfabeta.

Prasojo, Lantip Diat, \& Riyanto, Lantip. (2011). Teknologi Informasi Pendidikan. Yogyakarta: Gava Media.

Rahayu, Siti Kurnia. (2019). Perpajakan Indonesia: Konsep dan Aspek Formal. Yogyakarta: Graha Ilmu.

Rosdiana, Haula, \& Tarigan, Rasin. (2005). Perpajakan Teori dan Aplikasi. Jakarta: Raja Grafindo Persada.

Tahar, Afrizal, \& Rachman, Arnain Kartika. (2014). Pengaruh faktor internal dan faktor eksternal terhadap kepatuhan wajib pajak. Journal of Accounting and Investment, 15(1), 56-67.

Tapscott, Don. (1996). The digital economy: Promise and peril in the age of networked intelligence (Vol. 1). Newyork: McGraw-Hill.

Warsita, Bambang. (2008). Teknologi Pembelajaran Landasan Dan Aplikasinya. 
Analisis Strategi Pemerintah dalam Upaya Meningkatkan Kepatuhan Wajib Pajak Youtuber di Indonesia

Jakarta: Rineka Cipta, 135.

Wijaya, Suparna, \& Mahatma, Eka Abid. (2017). Analisa Upaya Peningkatan Penerimaan Perpajakan dari Penggalian Potensi Pajak Atas Penghasilan Youtuber. Jurnal Manajemen Keuangan Publik, 1(2), 125-130. 